\title{
Law Enforcement Against Perpetrators of Domestic Violence in terms of Legislation and Islamic Law
}

\author{
Fathul Djannah $^{2}$, Muhammad Rizal $^{1}$ \\ ${ }^{1}$ University of Panca Budi, Medan, Indonesia \\ ${ }^{2}$ State Islamic University of North Sumatera, Medan, Indonesia \\ Email: djannahf@gmail.com
}

\begin{abstract}
:
The aims of the study is to find out the law enforcement against perpetrators of domestic violence in terms of legislation and Islamic law. This research was conducted by examining library materials or secondary data relating to divorce on the grounds of domestic violence. Furthermore, using a normative juridical approach, it is intended to get clarity about divorce on the grounds of domestic violence. The result shows that the criminal law policy in the formulation of a system of criminal sanctions against perpetrators of a crime in domestic violence according to the provisions of the Domestic Violence Act (UUPKDRT) uses an alternative formulation system type. Criminal sentences in the form of imprisonment or fines with minimum and maximum rules. In Article 44 (physical violence), Article 45 (psychological violence), and Article 49 (neglect) there is no stipulation of a criminal minimum limit that only mentions a maximum limit
\end{abstract}

Keywords:

law enforcement; against; domestic violence; Islamic law

\section{Introduction}

Domestic violence is a problem in the family to maintain a family. Domestic violence can happen to anyone, including fathers, husbands, wives and children, as well as people who live in the family, but in general the understanding in domestic violence here is narrowed to mean abuse of the wife by the husband. This is understandable because most perpetrators in domestic violence are husbands. If we examine further many unhappy families, households that are always blown by storms of quarrel and squabbling. With this kind of situation any family will not be comfortable in living their lives. Cases like this very much happen in society.

But why are people reluctant to report their cases to the authorities? Even from the results of observations that the author made in the Military Court 1-02 Medan, during the Law on the Elimination of Domestic Violence there are only two cases decided by the Court submitted by the wife. This is because the victim is afraid that the case in his family will be processed in court because it is a disgrace in the family or the victim's lack of awareness of the legal protection given by the state.

The Majlis Hakim in setting a decision is not only guided by the Law on the Elimination of Domestic Violence (Domestic Violence), but the judge also considers the different statements of witnesses in deciding a case. In the two decisions on domestic violence decided by Palembang Military Court 1-04 there are a number of mitigating and aggravating matters, which between them are also different, decision No: 77-K/PM04/AD/VII/2012 submitted on: July 18, 2012 and adjourned on Monday, July 23, 2012 there were incriminating matters including the Defendant himself and the Defendant as the husband not protecting his wife. Whereas the things which helped the Defendant plead guilty and apologize to his wife, the Defendant and the Witness are still in a relationship between a husband and wife even though the case has been processed in Military 1-04 Palembang, and has never been convicted. 
Whereas in the decision No: 77-K / PM-04 / VII / 2012 which was submitted on July 18, 2012 and decided on Monday July 23, 2012, there were incriminating matters namely the Defendant was playing a vigilante, the Defendant as a husband did not protect, and the Defendant persecuted the victim, while the mitigating matters namely the Defendant had never been convicted, and the defendant pleaded guilty and apologized and regretted it. However, the verdict handed down in the case was very different, for the decision No: 77-K / PM-04 / VII / 2012 dated July 23, 2012, a 7-month sentence was imposed and an additional criminal was dismissed from military service and charged a fee of 1,000 rupiah, whereas verdict No: 77-K / PM04 / AD / VII / 2012 on July 23, 2012 obtained from the service as a soldier sentenced to 7 months and must be lived and charged a fee of 15000 rupiah.

\section{Review of Literature}

\subsection{Domestic Violence}

Domestic violence is a complex problem to solve. There are many reasons. It may be that the perpetrators of domestic violence really did not realize that what he had done was an act of domestic violence. Or, it could also be that the perpetrator is aware that the act he committed is an act of domestic violence. It's just that he ignored it because he was sheltering under certain norms that were already established in society. So consider domestic violence as a natural and personal thing.

In Indonesia, legally formally, this provision came into force in 2004. The mission of this Act is as an effort, endeavor for the elimination of domestic violence. With this provision, it means that the state can work to prevent domestic violence, take action against perpetrators of domestic violence, and protect victims due to domestic violence.

The definition of Domestic Violence in accordance with Law Number 23 of 2004 concerning the Elimination of Domestic Violence is very comprehensive. Domestic Violence (KDRT) has included understanding forms of violence in domestic violence cases. This can be said to be identical with the various incidents that often occur regarding forms of domestic violence and are aimed at victims / women and children. Although the substance of the regulation that domestic violence is an ordinary offense, but it still causes difficulties for law enforcement. Because oftentimes victims who initially complained about domestic violence cases, but in the midst of ongoing legal proceedings, victims suddenly wanted their cases to be stopped or dropped on the pretext of forgiving the perpetrators, or the victims' dependence on the perpetrators.

\subsection{Domestic Violence from the viewpoint of National Law}

Domestic Violence from the perspective of National Law, contained in Law no. 23 of 2004. Where the implementation of this Act is actually an implementation of the state which ratified the convention on the elimination of all forms of discrimination against women (Convention on the Elimination of All Forms of Discrimination / CEDAW) through Law No. 7 of 1984. Also based on the Declaration of Abolition Violence against Women born in the United Nations on 20 December 1993 and ratified by the Indonesian government. Even in Indonesia Law No. 23 of 2004 concerning 'Elimination of Domestic Violence has been passed.

Domestic Violence as stated in Law No.23 of 2004 concerning the Elimination of Domestic Violence, means that every act against a person, especially a woman, results in physical, sexual, psychological, and / or neglect or physical neglect of the home the household 
includes threats to carry out acts, coercion or deprivation of liberty unlawfully within the scope of the household.

The problem of domestic violence has received legal protection in Law Number 23 of 2004 which among others emphasizes that:

a. That every citizen has the right to get a sense of security and freedom from all forms of violence in accordance with the philosophy of the Pancasila and the 1945 Law of the Republic of Indonesia.

b. That all forms of violence, especially domestic violence is a violation of human rights, and crimes against human dignity and forms of discrimination must be removed.

c. Whereas victims of domestic violence, mostly women, must receive protection from the State and / or society to avoid and be free from violence or threats of violence, torture, or treatment that degrading human dignity and dignity.

$\mathrm{d}$. That based on the considerations referred to in letter a, letter b, letter c, and letter d, it is necessary to establish a law concerning the elimination of violence in household.

e. The act of violence committed by the husband against his wife is actually a heavy element in a criminal act, the legal basis is the Criminal Code (criminal law book) article 356 which outlines the contents of the article that reads: "Anyone who commits maltreatment against father, mother, wife or child is threatened with criminal punishment".

\subsection{Domestic Violence from the viewpoint of Religious Law}

Domestic violence does not only become a national legal context. But in a perfective understanding of religion, it has always been regulated in the Scriptures of Each Religion. Regarding the Elimination of Domestic Violence. Because in our country the majority are Muslim. Then I will also raise this Domestic Violence from the Islamic point of view. The following is an explanation of the explanation of domestic violence in an Islamic perspective.

Domestic Violence In the context of households, forms of violence often occur, both those affecting wives, children, domestic helpers, relatives or husbands. For example, there are husbands who beat their wives for various reasons, mothers who beat their children because they do not obey their parents' orders, or domestic servants who are mistreated by their employers because they have not finished their duties. All forms of domestic violence must basically be subject to sanctions because it is a form of criminality (jarimah).

It should be underlined that in the context of the household, the husband has an obligation to educate his wife and children to be obedient to Allah. This is according to the word of Allah Almighty which means: "O believers, take care of yourself and your family from the fires of hell ..." (Qs. At-Tahrim [66]: 6). In educating his wife and children, it may be forced to do with a "blow". Well, "beating" in the context of education or ta'dib is allowed with certain limitations and certain rules.

\section{Research Method}

Based on the formulation of the problem and research objectives, the authors use the normative juridical approach, because this research was conducted by examining library materials or secondary data relating to divorce on the grounds of domestic violence. Furthermore, using a normative juridical approach, it is intended to get clarity about divorce on the grounds of domestic violence. In other words, normative juridical research is library research, namely research on secondary data. 
The research location was carried out in Otmil 1-02 Medan located at Jalan Diponegoro Medan and Dilmil 02 medan on Jalan Lumban Surbakti Ringrood Medan. The Main Military Court in the technical field of justice, is tasked with carrying out a free Judicial Power in accordance with the vision and mission set by the Supreme Court of the Republic of Indonesia, and in the field of personnel carrying out guidance in accordance with applicable regulations.

\section{Discussion}

According to criminal law, there are several types of systems formulation of criminal sanctions (strafsoort), namely:

\subsection{Single / Imperative Formulation System}

The formulation system for the type of criminal sanctions / strafsoort is singular / imperative is the formulation system in which the type of criminal is formulated as the only criminal for the offense concerned. For this reason, this single formulation system can be in the form of imprisonment, confinement or even fines. Seen from the point of determination of the type of criminal, then this single formulation type is a legacy or a very striking influence of the classical school. This flow wants to objectify the criminal law from the personal characteristics of the offender. With this nature, then this flow initially arises not at all giving freedom to the judge to determine the type of crime and the size of the conviction.

Thus, it can be said that the system of formulating a single criminal threat is clearly a system of definite sentences, especially in terms of the type of criminal. In principle, a single formulation system actually by formulate policy should be avoided because it is "imperative". If described in more detail, the single / imperative formulation system has a dimension where the main weakness is very rigid because it is "obligatory". This aspect was sharply predicted by Barda Nawawi Arief as follows: "So the judge is confronted with a certain type of "definite sentence" and is very mechanical, because inevitably the Judge seems to have to impose a prison sentence automatically. Judges are not given the opportunity and leeway to determine other types of crimes that are appropriate for the defendant. Observing such characteristics (ie "rigid, imperative, dithionite and mechanical / automatic"), it is clearly seen that such a system is evidence of a legacy or a very striking influence of the classical school. As the classical school understands, it wants to objectify the criminal law from the subjective nature of the offender and does not give the judge the freedom to determine the type of crime and the size of the criminal sentence."

Furthermore, according to Barda Nawawi Arief, another weakness of the single formulation system is: "The difficulty of determining a rational measure of why a crime is only threatened with imprisonment, while others do not. Why, for example, for theft and embezzlement (Articles 362 and 372 of the Criminal Code) are threatened alternatively with a "jail or fine" penalty, whereas for fraud in Article 378 which is also a crime against property is only threatened with imprisonment.

However, even though a single formulation system has major weaknesses it does not mean such a system cannot be applied. If a single formulation system continues to be used, then to avoid the rigid nature there must be guidelines for judges in terms of establishing a single formulation system that becomes more flexible, soft and elastic. Concretely, there is freedom for judges not to impose a single imprisonment. 
If it is seen that such a guideline is replaced by another lighter type of criminal, the single system seems to be implemented as an alternative system, and if the judge can add or aggravate the single type of criminal set with another type of criminal so that it is as if the system That single can also be applied like a cumulative system.

\subsection{Alternative formulation system}

From the aspect of understanding and substance the alternative formulation system is a system in which imprisonment is formulated alternatively with other types of criminal sanctions based on sequences of types of criminal sanctions from the heaviest to the lightest. Thus the judge is given the opportunity to choose the type of criminal stated in the relevant article. In general, the formulation of alternatives starts with aspects of:

1) The selection of the type of criminal should be oriented to "criminal purposes", and

2) Should prioritize / give precedence to the type of criminal

3) lighter if the lighter penalties are in accordance with the purpose of punishment.

\subsection{Cumulative formulation system}

The cumulative formulation system has a special characteristic, namely the existence of criminal threats with redaction conjunctions "and" such as "imprisonment and fines". When analyzed further, the cumulative formulation system is identical to the single formulation system because it is "imperative", very rigid and "requires" the judge to impose a crime. Strictly speaking, there is no opportunity for the judge to choose the application of a crime which is considered the most suitable for the actions of the defendant because the judge is confronted with a definite type of crime (definite sentence). Nevertheless the cumulative formulation system when sharpened the polarization of thought turns out to also have some good, namely:

1) Provide legal certainty for the defendant that the criminal conviction refers to the cumulative crime, and

2) Providing more burdensome crimes to perpetrators / daders of criminal acts generalizing without seeing the actions case by case.

\subsection{Cumulative-alternative formulation system}

Judging from the terminology, the cumulative-alternative formulation system contains the following dimensions:

1) There is a cumulative formulation dimension. This aspect is a logical consequence of the material in the cumulative formulation of the special features of the word "and" in it;

2) There is an alternative formulation dimension in it

3) There is a single formulation dimension in it

This aspect is reflected in the cumulative-alternative formulation system in the presence of the words "and / or". From this context there is the existence of a single formulation where in the applicative policy the judge can / must choose one type of criminal. This formulation system mostly contains the threat of criminal "jail and / or fine". When compared with the previous formulation system, it seems that these cumulative alternatives are relatively quite significant, namely:

1) That the cumulative-alternative formulation system substantially also includes a single, cumulative and alternative formulation system so that it explicitly and implicitly covers the weaknesses of each of the formulation systems.

2) Whereas the cumulative-alternative formulation system is a pattern of the formulation system which directly is a combination of nuances of legal certainty (rechts-zekerheids) and nuances of justice; and 
3) Because it is a combination of nuances of justice and legal certainty (rechts-zekerheids), the main features of this formulation system in its applicable policies are flexible and accommodative.

To that end, for recommendations on future formulate / legislative policies or as a constituent ius in the future, legislators should make a cumulative-alternative formulation system. Knowledge of Criminal Law knowledge also recognizes the extent to which the system of criminal penalties (strafmaat) should be formulated. That is:

1) Fixed / definite sentence system in the form of a definite criminal threat.

2) The indefinite sentence system is in the form of a maximum length of criminal threats.

3) The indeterminate sentence system is not determined by a maximum criminal limit so that the law-making body fully submits the criminal policy (discretion) to the criminal implementing apparatus at a lower level, for example in determining the size, nature or duration of a criminal for a particular criminal offense.

4) Determine sentence system in the form of setting minimum / maximum limits of the duration of criminal threats.

The formulate policy on the type of system for formulating criminal sanctions (strafsoot) and the formulation of the length of criminal sanctions (strafmaat) ultimately lead to how to carry out criminal (strafmodus), so from the point of view of the guidance system (treatment) and its institutions / institutions. 23 of 2004 concerning PKDRT came into force, law enforcers used Article 356 of the Criminal Code to ensnare perpetrators of domestic violence. The article states: The penalties specified in Articles 351, 353, 354 and 355 can be added by one third:

1e. if the perpetrator commits the crime against his mother, legal father, wife (husband) or child. While Article 351 of the Criminal Code determines:

1) Torture is punishable by imprisonment for up to two years and eight months or a maximum fine of Rp135,000.

2) If the act is seriously injured, the perpetrator is sentenced to prison for up to 5 years

3) If the act makes the victim die, then the perpetrator is sentenced to prison for up to 7 years

4) With persecution equated to damage people's health intentionally

5) Attempts to commit this crime cannot be punished.

Looking at the sound of paragraph (4) of the above article, it must be interpreted that any act carried out by a person, be it beating, kicking, slapping, etc. that may result in damage to one's health, must be considered as persecution. At its implementation, the UUPKDRT uses alternative formulation system in the form of threats of imprisonment or fines. The form of this formulation is contained in chapter VIII (Article 44 (physical violence), Article 45 (psychological violence), Article 46, Article 47 and Article 48 (sexual violence), and Article 49 (neglect). Articles 44 of the Law on the Elimination of Domestic Violence determine:

1) every person who commits an act of physical violence within the scope of the household as referred to in Article 5 letter a, is sentenced to a maximum imprisonment of 5 (five) years or with a maximum fine of Rp.15,000,000.

2) In the case of acts as referred to in paragraph (1) resulting in the victim getting sick or seriously injured, shall be sentenced to a maximum of 10 years imprisonment or a maximum fine of Rp.30, 000,000.

3) In the case of the acts referred to in paragraph (2) resulting in the death of the victim, shall be sentenced to a maximum imprisonment of 15 years or a maximum fine of Rp.45,000,000. 
4) In the case of acts as referred to in paragraph (1) committed by a husband against a wife or vice versa which does not cause illness or obstruction to carry out occupational positions or livelihood or daily activities, shall be punished with a maximum of 4 months imprisonment or a maximum fine IDR 5,000,000

Article 45 of the Law on the Elimination of Domestic Violence determines:

1) Every person who commits an act of psychological violence within the scope of the household as referred to in Article 5 letter $\mathrm{b}$ shall be liable to a maximum imprisonment of 3 (three) years or a maximum fine of Rp.9,000,000.00 (nine million rupiah).

2) In the case of acts as referred to in paragraph (1) committed by a husband against a wife or vice versa which does not cause illness or obstruction to carry out occupational positions or livelihoods or daily activities, shall be liable to a maximum imprisonment of 4 (four) months or a maximum fine of Rp.3,000,000.00 (three million rupiah)

This provision on psychological violence is a lighter threat compared to other provisions on domestic violence. Though the consequences arising from psychological violence is as severe as physical violence because it is related to self-esteem even though this psychological violence does not leave physical injuries so it is difficult to see with the naked eye. But psychological violence can cause stress to the victim, from this stress can make the body weak so easily fall ill.

Article 46 of the Law on the Elimination of Domestic Violence determines: Every person who commits an act of sexual violence as referred to in Article 8 letter a is sentenced to a maximum imprisonment of 12 (twelve) years or a maximum fine of Rp.36,000,000.00 (thirty-six million rupiah).

Article 47 of the Law on the Elimination of Domestic Violence determines: Anyone who compels a person who lives in his household to have sexual relations as referred to in Article 8 letter $\mathrm{b}$ shall be sentenced to a maximum of 4 (four) years imprisonment and a maximum imprisonment of 15 (fifteen) years ) year or a minimum fine of Rp. 12,000,000.00 (twelve million rupiah) or a maximum fine of Rp.300,000,000.00 (three hundred million rupiah).

Article 48 of the Law on the Elimination of Domestic Violence determines: In the event that the acts referred to in Article 46 and Article 47 result in the victim receiving a wound that does not give any hope of being healed at all, experiencing a mental or mental disability for at least 4 (four) weeks continuously or not one year in a row, death or death of the fetus in the womb, or resulting in malfunctioning of reproductive organs, shall be punished with imprisonment for a minimum of 5 (five) years and a maximum imprisonment of 20 (twenty) years or a minimum fine of Rp.25,000,000.00 (twenty-five million rupiah) and a maximum fine of Rp.500,000,000.00 (five hundred million rupiah).

Article 49 of the Law on the Elimination of Domestic Violence determines: To be sentenced to a maximum imprisonment of 3 (three) years or a maximum fine of Rp. 15,000,000.00 (fifteen million rupiah), every person who:

1) Abandoning others in the scope of his household as referred to in Article 9 paragraph (1);

2) Abandoning others as referred to in Article 9 paragraph (2). 
In this case neglect does not explain the difference in criminal sanctions against economic abandonment or neglect of physical and spiritual livelihoods. If the negligence that occurs is only economic neglect, imprisonment of imprisonment is not appropriate, it would be better if the sentence imposed in the form of a fine with a minimum and maximum limits and compensation for victims who were abandoned. So the victims also feel that their rights are fulfilled by law.

The judge's decision in dropping the criminal offense is entirely in the hands of the judge. If examined more deeply on the UUPKDRT which adheres to alternative criminal formulations in the form of imprisonment or fines, the judge may decide by imposing just a fine. The existence of this choice will greatly benefit the offender, so that the offender does not need to undergo imprisonment within a certain period of time. Perpetrators are still free to roam around and there is a great possibility of insecurity and discomfort for the victim.

Whereas the inclusion of a maximum criminal threat only provides an opportunity for perpetrators to get low criminal sanctions due to the absence of minimal restrictions. The final part of the Law on the Elimination of Domestic Violence contains criminal provisions, with several forms of crime namely imprisonment, fines and supervision penalties. The amount of imprisonment and fines are in the range of one year to fifteen years, which seems to refer to the provisions in the Criminal Code, because the parameters of this criminal determination are never described at all, as also in other regulations. A parameter for the determination of criminal sanctions can only be created if it has been agreed in advance what would be the basis for thinking for criminal conviction.

With regard to the parameters of criminal determination, the Criminal Code Formulation Team has made a ranking based on the seriousness (gravity) of criminal acts. This ranking is divided into five levels using semantic scale techniques, from "very mild" to "very serious" with the note that a "very mild" crime is not subject to deprivation of liberty, while a very serious crime is a criminal offense that is subject to sanctions imprisonment of more than seven years.

It is unfortunate that this scale construction is not developed further. Therefore, again there is a problem in determining the proportion of each criminal act, both in terms of parity, rank and qualitative distance (parity, rank-ordering and spacing) between one criminal act and the one other. It is not explained about how the Formulation Team determines the categories of criminal acts, but it seems that certain methods have not yet been found so that the classification, ranking and determination of criminal sanctions are still similar to the Criminal Code, as also found in the PKDRT Law.

The effort to determine this proportion is not at all easy, but it is very important for consistency, not only at the level of legislation but also at the level of implementation by the judiciary later. Closely related to this is the parameter of punishment in the formulation of sanctions. Barda Nawawi and Soedarto have already complained about this condition. Certainly the absence of these parameters is not just a technical problem, but also a philosophical problem, due to the absence of a criminal philosophy. This condition is made worse because the legislation process as a political process that produces laws that apply to all the people of Indonesia, until now has not been satisfactory. The existence of logrolling or vote trading, pretty much gives color to this process. 
There are several things that should be considered together from the perspective of criminal theory and the purpose of the adoption of the PKDRT Law. These things are:

1) The application of short-term imprisonment in this case will not have any positive impact, even negative impacts such as stigma on the perpetrators, the bad influence of fellow prisoners in the prison, marital relationship damage, and other consequences on children in families experiencing domestic violence. The existence of short-term prison sentences has long been questioned in criminal law studies, because there are more negative impacts than goals that can be achieved.

2) If the judge does consider various things that are easy on the offender, then the judge should apply conditional criminal sanctions, which have no negative impact at all.

Even in this case the judge can provide certain conditions that can prevent the offender from repeating the act of domestic violence. Judges for example can require that the offender must not say or be rude to the victim, or neglect the household during the probationary period, or require the offender to undergo special counseling in overcoming the violent behavior. Seeing this description indeed, efforts to determine criminal sanctions must have been started through an in-depth study to capture the views and dynamics of the community, as well as the values that develop within it. Only in that way will an accurate picture of the determination of criminal sanctions be obtained in our various criminal provisions, including domestic violence.

\section{Conclusion}

The criminal law policy in the formulation of a system of criminal sanctions against perpetrators of a crime in domestic violence according to the provisions of the Domestic Violence Act (UUPKDRT) uses an alternative formulation system type. Criminal sentences in the form of imprisonment or fines with minimum and maximum rules. In Article 44 (physical violence), Article 45 (psychological violence), and Article 49 (neglect) there is no stipulation of a criminal minimum limit that only mentions a maximum limit. Whereas Article 46 and Article 47 regarding sexual violence mentioned in Article 48 clearly specify the minimum and maximum limits for imprisonment and criminal penalties. The criminal threat is alternative, the judge's decision to impose the criminal on the perpetrator is entirely in the hands of the judge. However, with the provision of alternative criminal threats, the judge may decide by imposing a criminal fine. This will greatly benefit the perpetrators because they do not need to undergo imprisonment within a certain period of time. Perpetrators are still free to roam around and there is a great possibility of insecurity and discomfort for the victim. In addition, the provisions regarding psychological violence are less threatening to criminal than other provisions in the domestic sphere of violence. Though the consequences arising from psychological violence is as severe as physical violence because it is related to self-esteem even though this psychological violence does not leave physical injuries so it is difficult to see by the eye.

\section{References}

Abdillah, Fahri. (2018). Bentuk-Bentuk Perubahan Sosial. https://blog.ruangguru.com.

Ali, Achmad. Menguak Tabir Hukum: Suatu Kajian Filosofis dan Sosiologis. Jakarta: Gunung Agung.

Ashram, Pasraman Ganesha Brahmachari. (2015). Anak-Anak dalam Pandangan Hindu di India. http://www.pasramanganesha.sch.id.

Badan Narkotika Nasional (BNN). (2017). Press Release Akhir Tahun 2017: Kerja Bersama 
Perang Melawan Narkoba. Jakarta: Humas BNN.

Badan Narkotika Nasional (BNN). (2017). Survei Nasional Penyalahgunaan Narkoba di 34 Provinsi Tahun 2017. Jakarta: Pusat Penelitian Data dan Informasi Badan Narkotika Nasional Republik Indonesia.

Dirdjosisworo, Soedjono. (2008). Pengantar Ilmu Hukum. Jakarta: PT. Raja Grafindo Persada. Friedman, Lawrence M. (2001). Hukum Amerika, Sebuah Pengantar, Penerjemah Wisnu Basuki, Tata Nusa, Jakarta.

Fuadi, Munir. (2003). Aliran Hukum Kritis: Paradigma Ketidakberdayaan Hukum. Bandung: Citra Aditya Bhakti.

Hadjon, Philipus M. (1987). Perlindungan Hukum Bagi Rakyat Indonesia. Surabaya: Bina Ilmu.

Hamzah, Andi. (2001). Bunga Rampai Hukum Pidana dan Acara Pidana. Jakarta: Ghalia Indonesia.

Hawari, Dadang. (2002). Penyalahgunaan dan Ketergantungan NAZA. Jakarta: Balai Penerbit FKUI.

Hawari, Dadang. (2012). Membina Keluarga Bahagia. Jakarta: Pustaka Antara.

KBBI Daring. (2018). Kamus Besar Bahasa Indonesia. Jakarta: Kementrian Pendidikan dan Kebudayaan.

Lamintang, P.A.F. (2011). Dasar-Dasar Hukum Pidana Indonesia. Bandung: Citra Aditya Bhakti.

Marlina. (2009). Peradilan Pidana Anak di Indonesia (Pengembangan Konsep Diversi dan Restorative Justice). Medan: PT. Refika Aditama.

Martono, Lydia Harlina Martono dan Satya Joewana. (2008). Peran Orang Tua dalam Mencegah dan Menanggulangi Penyalahgunaan Narkoba. Jakarta: Balai Pustaka.

Mertokusumo, Sudikno. (2009). Penemuan Hukum. Bandung: Citra Aditya Bakti.

Moeljanto. (2000). Azas-Azas Hukum Pidana, Cetakan Keenam. Jakarta: PT. Rhineka Cipta.

Muchsin. (2003). Perlindungan dan Kepastian Hukum bagi Investor di Indonesia. Surakarta: Universitas Sebelas Maret.

Nasriana. (2011). Perlindungan Hukum Pidana Bagi Anak di Indonesia. Jakarta: PT. Raja Grafindo Persada.

Nawawi, Imam. Terjemah Riyadhus Shalihin. Jakarta: Pustaka Amani.

Poernomo, Bambang. (1994). Azas-Azas Hukum Pidana, Cetakan Ketujuh. Bandung: Ghalia Indonesia.

Poerwadarminta, Wilfridus Josephus Sabarija. (2003). Kamus Umum Bahasa Indonesia. Jakarta: Balai Pustaka.

Prodjodikoro, Wiryono. (1989). Azas-Azas Hukum Pidana di Indonesia. Cetakan Kedua. Bandung: PT. Eresco.

Peraturan Menteri Kesehatan Nomor 41 Tahun (2017) tentang Perubahan Penggolongan Narkotika

Peraturan Pemerintah Nomor 2 Tahun (2002) tentang Tata Cara Perlindungan terhadap Korban dan Saksi dalam Pelanggaran Hak Asasi Manusia yang Berat

Purwono, Joko. (1993). Metode Penelitian Hukum. Surakarta: Departemen Pendidikan dan Kebudayaan Republik Indonesia, UNS.

Raharjo, Satjipto. (2000). Ilmu Hukum. Bandung: Citra Aditya Bakti.

Rahman, Fatchur. (1981). Ilmu Waris. Bandung: Al-Ma'arif.

Saleh, Roeslan. (2003). Perbuatan Pidana dan Pertanggungjawaban Pidana. Jakarta: Aksara Baru.

Santrock, J.W. (2003). Adolescence: Perkembangan Remaja, Edisi Keenam. Alih Bahasa oleh Shinto B. Adelar dan Sherly Saragih. Jakarta: Erlangga.

Soekanto, Soerjono. (1986). Pengantar Penelitian Hukum. Jakarta: UI Press. 
Soekanto, Soerjono. (1993). Faktor-Faktor yang Mempengaruhi Penegakan Hukum, Cetakan Ketiga. Jakarta: Radja Grafindo.

Soekanto, Soerjono dan Sri Mamudji. (2003). Penelitian Hukum Normatif: Suatu Pengantar Singkat. Jakarta: Raja Grafindo Persada.

Sunggono, Bambang. (2007). Metodologi Penelitian Hukum. Jakarta: Raja Grafindo Persada.

Supramono, Gatot. (2001). Hukum Narkotika Indonesia. Jakarta: Djambatan.

Syâkir, Mahmûd. (2001). Tafsir ath-Thabari: Dhabth wa Ta'lîq, Cetakan Kesatu. Beirut: Dâr Ihyâ' At-Turâts Al-'Arabi.

Tobing, Tommy Albert. (2017). Materi Diskusi Prospek Implementasi Sistem Peradilan Pidana Anak di Indonesia. Jakarta.

Undang-Undang Dasar Negara Republik Indonesia Tahun 1945.

Undang-Undang Nomor 1 tahun 1974 tentang Perkawinan.

Undang-Undang Nomor 4 Tahun 1979 tentang Kesejahteraan Anak.

Undang-Undang Nomor 3 Tahun 1997 tentang Pengadilan Anak.

Undang-Undang Nomor 5 Tahun 1997 tentang Psikotropika.

Undang-Undang Nomor 39 Tahun 1999 tentang Hak Asasi Manusia (HAM).

Undang-Undang Nomor 23 Tahun 2002 tentang Perlindungan Anak.

Undang-Undang Nomor 13 Tahun 2006 tentang Perlindungan Saksi dan Korban.

Undang-Undang Nomor 35 Tahun 2009 tentang Narkotika.

Undang-Undang Nomor 11 Tahun 2012 tentang Sistem Peradilan Pidana Anak.

Undang-Undang Nomor 35 Tahun 2014 tentang Perubahan atas Undang-Undang Nomor 23

Tahun 2002 tentang Perlindungan Anak.

Witanto, D.Y. (2012). Hak dan Kedudukan Anak Luar Kawin. Jakarta: Kencana. 